\title{
Deleted In Azoospermia-Like
}

National Cancer Institute

\section{Source}

National Cancer Institute. Deleted In Azoospermia-Like. NCI Thesaurus. Code C114634.

Deleted in azoospermia-like (295 aa, $33 \mathrm{kDa}$ ) is encoded by the human DAZL gene. This protein plays a role in gametogenesis. 